\title{
TANAMAN APU-APU DALAM MENURUNKAN KADAR LIMBAH RUMAH SAKIT
}

\author{
Arista Tia Gata ${ }^{1)}$
}

\begin{abstract}
Abstrak
Limbah rumah sakit adalah semua limbah yang dihasilkan dari kegiatan rumah sakit dalam bentuk padat, cair dan gas. Kandungan BOD, COD, dan amonia bebas dalam limbah cair rumah sakit mengandung bahan berbahaya yang dapat menimbulkan paparan/dampak terhadap lingkungan dan masyarakat yang mempunyai resiko dari hasil yang ditimbulkan serta usaha mengatasinya.

Penelitian eksperimen ini menggunakan rancangan pretest-posttest control group untuk melihat kemampuan tanaman apu-apu dengan variasi jumlah apu-apu, waktu kontak, dalam menurunkan $\mathrm{BOD}, \mathrm{COD}$, dan ammonia.

Hasil yang diperoleh efektivitas berat apu-apu terhadap penurunan BOD yaitu pada berat $1,5 \mathrm{~kg}$ dan lama waktu kontak efektif adalah pada hari ke-9, efektivitas berat apu-apu terhadap penurunan COD yaitu pada berat yang paling efektif adalah berat 1,5 kgdan lama waktu kontak efektif adalah pada hari ke-9, efektivitas berat apu-apu terhadap penurunan amoniak yaitu pada berat $1,5 \mathrm{~kg}$ dan lama waktu kontak yang efektif adalah pada hari ke-9.
\end{abstract}

Kata kunci : limbah rumah sakit, apu-apu

${ }^{1)}$ Alumni Prodi D4 Kesehatan Lingkungan Poltekkes Tanjungkarang

\section{PENDAHULUAN}

Rumah sakit adalah instalasi pelayanan kesehatan bagi masyarakat dengan karakteristik tersendiri yang dipengaruhi oleh perkembangan ilmu pengetahuan kesehatan, kemajuan teknologi dan kehidupan sosial masyarakat yang harus tetap mampu meningkatkan pelayanan yang lebih bermutu dan terjangkau oleh masyarakat agar terwujudnya derajat kesehatan yang setinggi-tingginya. Sehingga dengan kebijakan legai yang mengharuskan pihak rumah sakit agar menyediakan pengolahan limbah yang dihasilkan dalam pelaksanaannya, rumah sakit menghasilkan limbah yang terdiri dari limbah padat, limbah gas, dan limbah cair baik dari limbah medis maupun limbah non-medis (Asmadi, 2013).

Limbah rumah sakit adalah semua limbah yang dihasilkan dari kegiatan rumah sakit dalam bentuk padat, cair dan gas. Air limbah rumah sakit mengandung polutan yang bersifat toksic, infeksius, bahkan radioaktif sehingga berpotensi menimbulkan dampak terhadap pencemaran lingkungan dan kesehatan masyarakat (Asmadi, 2013).

Kandungan BOD, COD, dan amonia bebas dalam limbah cair rumah sakit mengandung bahan berbahaya yang dapat menimbulkan paparan/dampak terhadap lingkungan dan masyarakat yang mempunyai resiko dari hasil yang ditimbulkan serta usaha mengatasinya. Tumbuhan eceng gondok (Eichhornia crassipes) (Mart), Solm) dapat digunakan karena mempunyai daya regenerasi yang cepat, sangat peka terhadap keadaan yang unsur haranya di dalam air kurang mencukupi tetapi mempunyai respon terhadap konsentrasi unsur hara yang tinggi. Akar eceng gondok berupa serabut yang penuh dengan bulu akar, tudung akarnya berwarna merah. Bulu-bulu akar berfungsi sebagai pegangan atau jangkar, dan sebagian besar berguna untuk mengabsorbsi zat-zat makanan dalam air (Eames dan Daniel, 1947 dalam Nurhayati, 1989). Pemanfaatan tumbuhan eceng gondok pada pengolahan air limbah telah banyak dilakukan. Penelitian telah dilakukan untuk mengetahui kemampuan penyerapan eceng gondok terhadap ammonia yang terkandung dalam limbah cair rumah sakit berdasarkan umur dan lama kontak yang berbeda (Wolverton et al, 1986). Selain eceng gondok, ada tanaman lain yaitu tanaman apuapu (Pistia stratiotes). Penelitian bertujuan menggunakan tanaman apu-apu untuk pengolahan limbah cair di rumah sakit. Tanaman apu-apu berfungsi sebagai pengikat unsur-unsur yang bersifat toksik atau beracun dari lingkungan sekitarnya dan sensitif terhadap 
semua perubahan lingkungan baik secara fisik maupun kimia. Adapun metode yang dipakai adalah metode fitoremediasi yang menggunakan tumbuhan tanaman apu-apu (Pistia stratiotes). Sedangkan fitoremediasi suatu upaya untuk menghilangkan, mengekstrak, dan menurunkan kandungan berbahaya di dalam air dengan menggunakan tanaman air. Sehingga pada metode ini diharapkan pada air limbah rumah sakit memenuhi standar baku mutu air limbah dan tidak mencemari lingkungan sekitar.

\section{METODE PENELITIAN}

Penelitian yang digunakan adalah penelitian eksperimen dengan desain rancangan pretest-posttest control group, yaitu pengujian sebelum dan sesudah kelompok sampel dilakukan perlakuan. Penelitian ini meneliti kemampuan tanaman apu-apu dengan variasi jumlah apu-apu, waktu kontak, dalam menurunkan BOD, COD, dan ammonia. Jumlah apu-apu dan waktu kontak dibedakan menjadi apu-apu dengan waktu tinggal (control), $0,5 \mathrm{~kg}$ tanaman apu-apu dengan waktu kontak 3 hari, 6 hari, 9 hari. $1 \mathrm{~kg}$ tanaman apu-apu dengan waktu kontak 3 hari, 6 hari, 9 hari. $1,5 \mathrm{~kg}$ tanaman apu-apu dengan waktu kontak 3 hari, 6 hari, 9 hari.

Penelitian dilakukan pada bulan Mei sampai dengan bulan Juni 2017 bertempat di Rumah Sakit TK.IV 02.07.04/DKT, Kota Bandar Lampung. Sampel diambil di bagian outlet karena pada tahap sebelumnya terdapat pengolahan yang telah dilakukan, hanya saja hasil outlet yang dikeluarkan masih memiliki nilai di atas baku mutu yang sudah di tetapkan. Untuk jumlah variasi yang digunakan berjumlah 9 variasi. Pengulangan sebanyak 3 kali. Pemeriksaan parameter kimia (COD, amonia bebas, $\mathrm{BOD}_{5}$ ) dengan membandingkan pada Peraturan Gubernur No. 7 tahun 2010 tentang Baku Mutu Air Limbah bagi Usaha dan/atau kegiatan di Provinsi Lampung.

\section{HASIL}

\section{Penurunan kadar BOD}

Pada 0 hari, hari yang dianggap sebagai awal sebelum dilakukan perlakuan air limbah yang dimasukkan ke dalam setiap bak sebanyak 9 liter baik dalam bak perlakuan ataupun dalam bak control (bak tanpa tanaman apu-apu). Dan tanaman apu-apu sebagai objek yang digunakan untuk melakukan penyerapan kadar BOD dalam air limbah ditanamkan sesuai dengan jumlah pada masing-masing bak yang digunakan. Penanaman ini disesuaikan beratnya $(0,5 \mathrm{~kg}, 1$ $\mathrm{kg}$, dan $1,5 \mathrm{~kg}$ ) bertujuan untuk melihat mana tanaman yang dapat menyerap paling banyak berdasarkan dengan lama waktu kontak ( 3 hari, 6 hari, dan 9 hari) tanaman dengan air limbah.

Penurunan BOD pada hari ke-0 baik bạk kontrol hingga bak yang berisi tanaman memiliki nilai BOD yang tinggi. Lalu penurunan terjadi saat memasuki hari ke-3 hingga hari ke-9. Persentase penurunan terendah terjadi pada hari ke-3 dengan berat 0.5 $\mathrm{kg}$ yaitu $11,67 \%$ dan penurunan tertinggi terjadi pada hari ke-9 dengan berat $1.5 \mathrm{~kg}$ yaitu $55,76 \%$. Dan jika dilihat dari tabel di atas dapat dinyatakan bahwa penurunan yang paling tinggi terjadi pada bak dengan berat tanaman apu-apu $1,5 \mathrm{~kg}$ dan lama hari 9 hari.

Tabel 1 menunjukkan hasil P-value 0.000 yang berarti $0.01<0.05$ sehingga dapat diartikan bahwa terdapat perbedaan dalam kadar BOD dengan variasi berat tanaman $0,0,5 \mathrm{~kg}, 1 \mathrm{~kg}$, $1.5 \mathrm{~kg}$. Pada kelompok kontrol $0 \mathrm{~kg}$ kadar minimum BOD 30.15 dan maksimum 45.60 . Kadar BOD maksimum pada berat $1 \mathrm{~kg}$ sebesar 42.80. Kadar BOD minimum pada berat $1,5 \mathrm{~kg}$ sebesar 12.65. Hasil dari uji Mann-Whitney dapat dilihat kelompok yang mempunyai perbedaan penurunan kadar BOD (P) $<0.05$ adalah $0 \mathrm{~kg}$ dan $0.5 \mathrm{~kg}, 0 \mathrm{~kg}$ dan $1 \mathrm{~kg}, 0 \mathrm{~kg}$ dan $1.5 \mathrm{~kg}$. Pada hasil berat tanaman yang lain menyatakan bahwa tidak terdapat perbedaan dalam penurunan kadar penurunan BOD.

Berdasarkan waktu kontak menunjukkan nilai P-value 0.000 yang berarti $0.000<0.05$ sehingga dapat diartikan bahwa terdapat perbedaan dalam kadar BOD dengan rentan waktu 0 hari, 3 hari, 6 hari, dan 9 hari. Kadar BOD maksimum pada hari ke-3 sebesar 45.60 . Kadar BOD minimum pada hari ke-9 sebesar 12.65

Tabel 1 juga menunjukkan hasil dari uji Mann-Whitney dapat dilihat kelompok yang mempunyai perbedaan penurunan kadar BOD $(P)<0.05$ adalah waktu kontak 0 hari dan 3 hari, 0 hari dan 6 hari, 0 hari dan 9 hari, 3 hari dan 6 hari, 3 hari dan 9 hari, serta 6 hari dan 9 hari. Pada penurunan BOD ini yang efektif dalam menurunkan kadar BOD adalah pada hari yang ke 6 dengan nilai maksimum 40,45 dan nilai minimum adalah 20,25 . 
Tabel 1. Hasil uji berat tanaman dan lama waktu kontak dalam penurunan BOD

\begin{tabular}{lllllll}
\hline & & $\mathrm{N}$ & $\begin{array}{l}\text { Median } \\
\text { (minimum-maksimum) }\end{array}$ & $P$ & $\begin{array}{l}\text { Chi- } \\
\text { Square }\end{array}$ & $D F$ \\
\hline BOD & $0 /$ control & 36 & $39.05(30.15-45.60)$ & 0.01 & 16.84 & 3 \\
& $0.5 \mathrm{~kg}$ & 12 & $29.95(19.25-42.50)$ & & & \\
$1 \mathrm{~kg}$ & 12 & $28.60(16.95-42.80)$ & & & \\
& $1.5 \mathrm{~kg}$ & 12 & $31.65(12.65-42.60)$ & & &
\end{tabular}

Uji Kruskal-wallis. Uji post-hoc Mann- whitney;

Berat tanaman 0 vs $0.5 \mathrm{~kg}(P) 0.008<0.05$

Berat tanaman $0 \mathrm{vs} 1 \mathrm{~kg}(P) 0.004<0.05$

Berat tanaman $0 \mathrm{vs} 1.5 \mathrm{~kg}(P) 0.004<0.05$

\begin{tabular}{|c|c|c|c|c|c|c|}
\hline \multicolumn{7}{|c|}{ Hasil uji lama waktu kontak dengan penurunan BOD } \\
\hline & & $\mathrm{N}$ & $\begin{array}{l}\text { Median } \\
\text { (minimum-maksimum) }\end{array}$ & $P$ & $\begin{array}{l}\text { Chi- } \\
\text { Square }\end{array}$ & $D F$ \\
\hline \multirow[t]{4}{*}{ BOD } & 0 hari & 18 & $42.60(37.20-44.12)$ & 0.000 & 39.246 & 3 \\
\hline & 3 hari & 18 & $37.55(28.26-45.60)$ & & & \\
\hline & 6 hari & 18 & $30.60(20.25-40.42)$ & 3 & & \\
\hline & 9 hari & 18 & $27.17(12.65-38.60)$ & & & \\
\hline \multicolumn{7}{|c|}{ Uji Kruskal-wallis. Uji post-hoc Mann- whitney; } \\
\hline \multicolumn{7}{|c|}{ Lama waktu kontak 0 hari vs 3 vs 6 hari vs 9 hari $(P) 0.005<0.05$} \\
\hline \multicolumn{7}{|c|}{ Lama waktu kontak 3 hari vs 6 hari vs 9 hari $(P) 0.000<0.05$} \\
\hline \multicolumn{7}{|c|}{ Lama waktu kontak 6 hari vs 9 hari $(P) 0.000<0.05$} \\
\hline
\end{tabular}

\section{Penurunan kadar COD}

Pada 0 hari, hari yang dianggap sebagai awal sebelum dilakukan perlakuan air limbah yang dimasukkan ke dalam setiap bak sebanyak 9 liter baik dalam bak perlakuan ataupun dalam bak control (bak tanpa tanaman apu-apu). Dan tanaman apu-apu sebagai objek yang digunakan untuk melakukan penyerapan COD dalam air limbah ditanamkan sesuai dengan jumlah pada masing-masing bak yang digunakan. Penanaman ini disesuaikan beratnya $(0,5 \mathrm{~kg}, 1$ $\mathrm{kg}$, dan $1,5 \mathrm{~kg}$ ) bertujuan untuk melihat mana tanaman yang dapat menyerap paling banyak berdasarkan dengan lama waktu kontak ( 3 hari, 6 hari, dan 9 hari) tanaman dengan air limbah.

Penurunan kadar COD berdasarkan perlakuan dan waktu kontak, pada hari ke-0 baik bak kontrol hingga bak yang berisi tanaman memiliki nilai COD yang tinggi. Lalu penurunan terjadi saat memasuki hari ke-3 hingga hari ke-9. Persentase penurunan terendah terjadi pada hari ke- 3 dengan berat 0.5 $\mathrm{kg}$ yaitu $3.99 \%$ dan penurunan tertinggi terjadi pada hari ke-9 dengan berat $1.5 \mathrm{~kg}$ yaitu 61.82 $\%$. Dan jika dilihat dari tabel di atas dapat dinyatakan bahwa penurunan yang paling tinggi terjadi pada bak dengan berat tanaman apu-apu $1,5 \mathrm{~kg}$ dan lama hari 9 hari.

Tabel 2 menunjukkan hasil bahwa nilai Pvalue 0.005 yang berarti $0.005<0.05$ sehingga dapat diartikan bahwa terdapat perbedaan dalam kadar COD dengan variasi berat tanaman $0 \mathrm{~kg}, 0,5 \mathrm{~kg}, 1 \mathrm{~kg}, 1.5 \mathrm{~kg}$. Pada kelompok kontrol $0 \mathrm{~kg}$ kadar minimum COD 80.00 dan maksimum 114.00. Kadar COD maksimum pada berat $1 \mathrm{~kg}$ sebesar 110.00 . Kadar COD minimum pada berat $1,5 \mathrm{~kg}$ sebesar 32.00 . Hasil dari uji Mann-Whitney dapat dilihat kelompok yang mempunyai perbedaan penurunan kadar COD $(\mathrm{P})<0.05$ adalah $0 \mathrm{~kg}$ dan $0.5 \mathrm{~kg}, 0 \mathrm{~kg}$ dan $1 \mathrm{~kg}, 0 \mathrm{~kg}$ dan $1.5 \mathrm{~kg}$. Pada hasil berat tanaman yang lain menyatakan bahwa tidak terdapat perbedaan dalam penurunan kadar penurunan COD.

Pada hasil uji waktu kontak, nilai P-value 0.000 yang berarti $0.000<0.05$ sehingga dapat diartikan bahwa terdapat perbedaan dalam kadar COD dengan rentan waktu 0 hari, 3 hari, 6 hari, dan 9 hari. Kadar COD maksimum pada hari ke-3 sebesar 114.00. Kadar COD minimum pada hari ke-9 sebesar 32.00. Hasil dari uji Mann-Whitney dapat dilihat kelompok yang mempunyai perbedaan penurunan kadar COD (P) $<0.05$ adalah waktu kontak 0 hari dan 3 hari, 0 hari dan 6 hari, 0 hari dan 9 hari, dan 3 hari dan 9 hari. Pada hasil hari yang lain menyatakan bahwa tidak terdapat perbedaan dalam penurunan kadar COD. 
Tabel 2. Hasil uji berat lama tanaman dan waktu kontak dalam penurunan COD

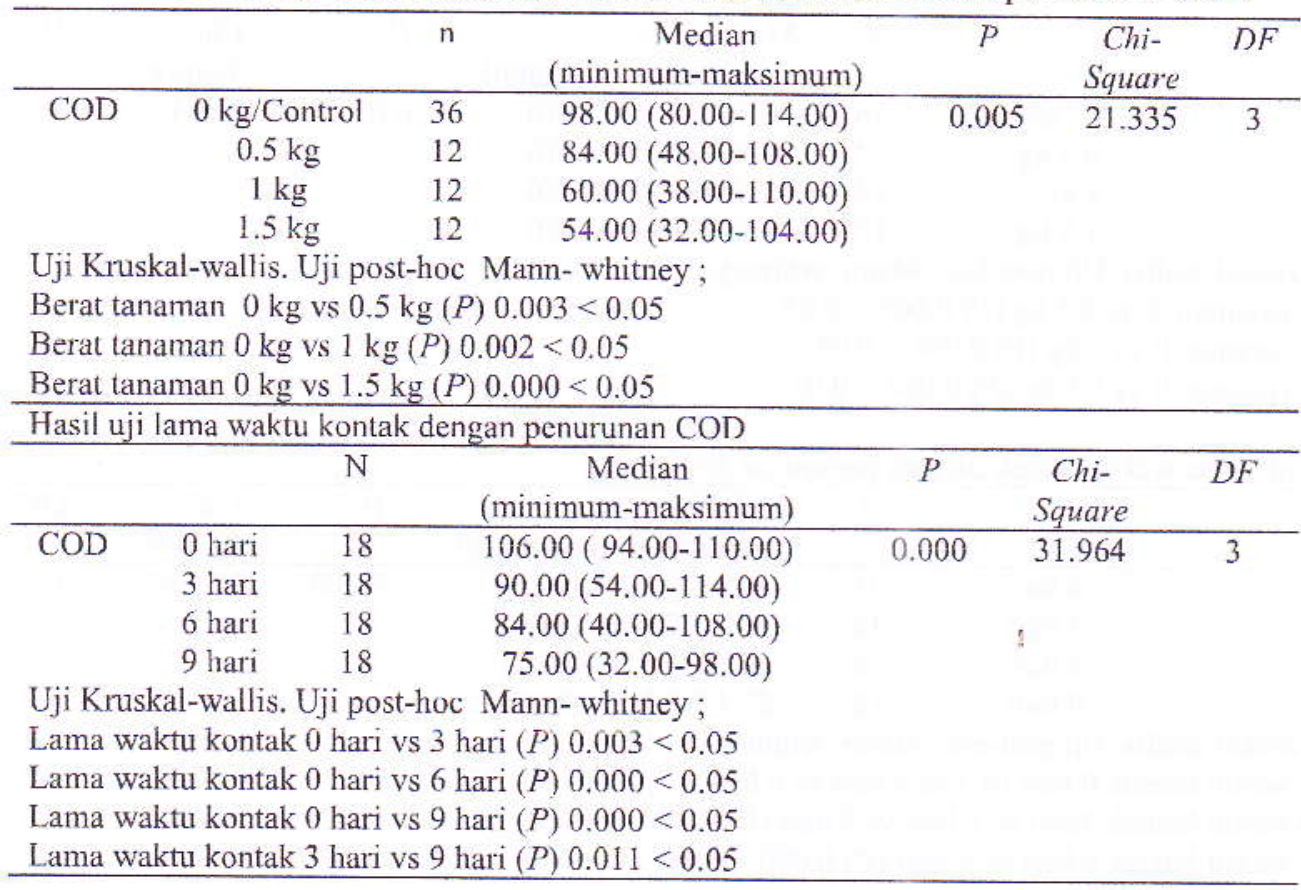

\section{Penurunan kadar amonia}

Pada 0 hari, hari yang dianggap sebagai awal sebelum dilakukan perlakuan air limbah yang dimasukkan ke dalam setiap bak sebanyak 9 liter baik dalam bak perlakuan ataupun dalam bak control (tanpa tanaman). Dan tanaman apuapu sebagai objek yang digunakan untuk melakukan penyerapan kadar amonia dalam air limbah ditanamkan sesuai dengan jumlah pada masing-masing bak yang digunakan. Penanaman ini disesuaikan beratnya $(0,5 \mathrm{~kg}, 1$ $\mathrm{kg}$, dan $1,5 \mathrm{~kg}$ ) bertujuan untuk melihat mana tanaman yang dapat menyerap paling banyak berdasarkan dengan lama waktu kontak ( 3 hari, 6 hari, dan 9 hari) tanaman dengan air limbah. Penurunan kadar amoniak berdasarkan perlakuan dan waktu kontak, penurunan kadar amoniak pada hari ke-0 baik bak kontrol hingga bak yang berisi tanaman memiliki nilai amoniak yang tinggi. Lalu penurunan terjadi saat memasuki hari ke-3 hingga hari ke-9. Persentase penurunan terendah terjadi pada hari ke-3 dengan berat $0.5 \mathrm{~kg}$ yaitu $5,19 \%$ dan penurunan tertinggi terjadi pada hari ke-9 dengan berat $1.5 \mathrm{~kg}$ yaitu $97,12 \%$. Dan jika dilihat dari tabel di atas dapat dinyatakan bahwa penurunan yang paling tinggi terjadi pada bak dengan berat tanaman apu-apu 1,5 $\mathrm{kg}$ dan lama hari 9 hari.
Tabel 3 menunjukkan hasil bahwa nilai Pvalue 0.00 yang berarti $0.00<0.05$ sehingga dapat diartikan bahwa terdapat perbedaan dalam kadar amonia dengan variasi berat tanaman $0 \mathrm{~kg}, 0,5 \mathrm{~kg}, 1 \mathrm{~kg}, 1.5 \mathrm{~kg}$. Pada kelompok kontrol $0 \mathrm{~kg}$ kadar minimum amoniak 5.00 dan maksimum 6.93. Kadar amoniak maksimum pada berat $0.5 \mathrm{~kg}$ sebesar 6.20. Kadar amoniak minimum pada berat 1,5 $\mathrm{kg}$ sebesar 0.15. Hasil dari uji Mann-Whitney dapat dilihat kelompok yang mempunyai perbedaan penurunan kadar amoniak $(\mathrm{P})<0.05$ adalah $0 \mathrm{~kg}$ dan $0.5 \mathrm{~kg}, 0 \mathrm{~kg}$ dan $1 \mathrm{~kg}, 0 \mathrm{~kg}$ dan $1.5 \mathrm{~kg}$. Pada hasil berat tanaman yang lain menyatakan bahwa tidak terdapat perbedaan dalam penurunan kadar penurunan amoniak.

Pada hasil uji waktu kontak, diperoleh nilai $\mathrm{P}$-value 0.001 yang berarti $0.000<0.05$ sehingga dapat diartikan bahwa terdapat perbedaan dalam kadar amoniak dengan rentan waktu 0 hari, 3 hari, 6 hari, dan 9 hari. Kadar amoniak maksimum pada hari ke-3 sebesar 6.95. Kadar amoniak minimum pada hari ke-9 sebesar 0.15. Hasil dari uji Mann-Whitney dapat dilihat kelompok yang mempunyai perbedaan penurunan kadar amoniak $(\mathrm{P})<0.05$ adalah waktu kontak 0 hari dan 3 hari, 0 hari dan 6 hari, 0 hari dan 9 hari. Pada hasil hari yang lain menyatakan bahwa tidak terdapat perbedaan dalam penurunan kadar penurunan amoniak. 
Tabel 3. Hasil uji variasi berat tanaman dn lama waktu kontak dengan penurunan amoniak

\begin{tabular}{|c|c|c|c|c|c|c|}
\hline & & $\mathrm{n}$ & $\begin{array}{c}\text { Median } \\
\text { (minimum-maksimum) }\end{array}$ & $P$ & $\begin{array}{c}\text { Chi- } \\
\text { Square }\end{array}$ & $7) F$ \\
\hline \multirow[t]{4}{*}{ amonia } & Control & 36 & $6.02(5.00-6.93)$ & 0.00 & 38.738 & 3 \\
\hline & $0.5 \mathrm{~kg}$ & 12 & $3.35(0.50-6.20)$ & & & \\
\hline & $1 \mathrm{~kg}$ & 12 & $2.20(0.35-5.92)$ & & & \\
\hline & $1.5 \mathrm{~kg}$ & 12 & $1.90(0.15-5.70)$ & & & \\
\hline \multicolumn{7}{|c|}{ Uji Kruskal-wallis. Uji post-hoc Mann- whitney; } \\
\hline \multicolumn{7}{|c|}{ Berat tanaman $0 \mathrm{~kg}$ vs $0.5 \mathrm{~kg}(P) 0.000<0.05$} \\
\hline \multicolumn{7}{|c|}{ Berat tanaman $0 \mathrm{~kg}$ vs $1 \mathrm{~kg}(P) 0.000<0.05$} \\
\hline \multicolumn{7}{|c|}{ Berat tanaman $0 \mathrm{~kg}$ vs $1.5 \mathrm{~kg}(P) 0.000<0.05$} \\
\hline \multicolumn{7}{|c|}{ Hasil uji lama waktu kontak dengan penurunan amoniak } \\
\hline & & n & $\begin{array}{c}\text { Median } \\
\text { (minimum-maksimum) }\end{array}$ & $P$ & $\begin{array}{l}\text { Chi- } \\
\text { Square }\end{array}$ & $D F$ \\
\hline \multirow[t]{4}{*}{ Amonia } & 0 hari & 18 & $5.99(5.30-6.93)$ & 0.001 & 16.864 & 3 \\
\hline & 3 hari & 18 & $4.98(1.95-6.95)$ & & & \\
\hline & 6 hari & 18 & $4.32(0.75-6.64)$ & : & & \\
\hline & 9 hari & 18 & $3.30(0.15-6.40)$ & & & \\
\hline \multicolumn{7}{|c|}{ Uji Kruskal-wallis. Uji post-hoc Mann-whitney; } \\
\hline \multicolumn{7}{|c|}{ Lama waktu kontak 0 hari vs 3 hari $(P) 0.000<0.05$} \\
\hline \multicolumn{7}{|c|}{ Lama waktu kontak 0 hari vs 6 hari $(P) 0.017<0.05$} \\
\hline \multicolumn{7}{|c|}{ Lama waktu kontak 0 hari vs 9 hari $(P) 0.000<0.05$} \\
\hline
\end{tabular}

\section{Penurunan $\mathrm{pH}$}

Perubahan $\mathrm{pH}$ pada air limbah cair rumah sakit DKT menandakan bahwa sudah terjadi aktivitas mikroorganisme yang merubah bahanbahan organik dalam air limbah. Rata-rata $\mathrm{pH}$ yang diberikan perlakuan menggunakan apuapu dan waktu kontak akan berubah pada hari ke 3 perlakuan termasuk kontrol. Pada hari ke 6 , dan hari ke 9 perlakuan terjadi perubahan $\mathrm{pH}$ tetapi tidak mengalami penurunan yang berarti., kecuali pada perlakuan kontrol.

Kenaikan maupun penurunan nilai $\mathrm{pH}$ yang terjadi selama proses fitoremediasi disebabkan aktivitas biokimia mikroorganisme yang terdapat pada limbah cair rumah sakit DKT dan akar tumbuhan apu-apu selama perlakuan. Tumbuhan apu-apu mampu hidup dalam tingkat keasaman 4,5 hingga 10 . Namun, pH optimun untuk pertumbuhan eceng gondok yaitu kisaran $\mathrm{pH} 7$ hingga 7,5.

\section{PEMBAHASAN}

Penelitian ini mengamati factor yang dapat mempengaruhi kadar BOD, COD dan amoniak dalam pengolahan limbah Rumah Sakit TK IV 02.07.04 / DKT dengan menggunakan variable lama waktu kontak dan variasi berat tanaman apu-apu. Dalam penelitian ini tanaman apu-apu yang telah diaklimitasi ditanam pada air dengan variasi berat $0.5 \mathrm{~kg}, 1 \mathrm{~kg}$, dan $1.5 \mathrm{~kg}$ dengan lama waktu kontak 3 hari, 6 hari, dan 9 hari. BOD (Biology Oxyge Demand) adalah banyaknya oksigen dalam $\mathrm{mg} / \mathrm{L}$ yang dibutuhkan oleh mikroorganisme dalam kondisi khusus untuk menguraikan benda organic dalam kondisi aerobic. COD (Chemical Oxyge Demand) sama seperti BOD yaitu jumlah oksigen yang digunakan untuk menguraikan seluruh bahan organic yang terkandung di dalam air melalui proses kimiawi. Angka BOD dan COD merupakan ukuran bagi pencemaran air oleh zat-zat organic, yang secara alamiah dapat dioksidasikan melalui proses mikrobiologi dan mengakibatkan kurangnya kadar DO (Disolved Oxygen) dalam air. Sedangkan amoniak adalah gas tak berwarna dengan bau khas yang menyengat. Amoniak biasa banyak terkandung dalam limbah cair. Limbah cair yang mengandung amonia sampai $1000 \mathrm{mg} / \mathrm{L}$ sampai $250 \mathrm{mg} / \mathrm{L}$ yang dapat menimbulkan resiko gangguan pada biota air yang hidup di badan air.

\section{Penurunan BOD}

Nilai BOD pengukuran pada limbah cair rumah sakit TK IV 02.07.04 mengalami penurunan berdasarkan berat tanaman dengan waktu. Selama penelitian dari waktu 0 hari (control) sampai dengan hari ke-9, kadar BOD terkadang naik ataupun bahkan turun. Perubahan nilai BOD pada limbah cair rumah sakit DKT selama proses fitoremediasi terjadi akibat aktivitas biokimia mikroorganisme yang terdapat dalam limbah cair rumah sakit DKT yang terjadi pada bagian akar tanaman apu-apu. BOD yang terserap oleh akar kemudian 
mengalami translokasi di dalam tumbuhan dan dilokasikan pada jaringannya. Pada settiap perlakuan dengan waktu kontak, tanaman apuapu dilakukan aklimitasi yang dilakukan pada air bersih selama kurang lebih 3 hari untuk menyesuaikan tumbuhan dengan lingkungan yang baru. (Puspita,2011).

Pada tabel 1 menunjukan bahwa nilai yang paling banyak menyerap kadar BOD adalah pada waktu 9 hari dengan berat tanaman apuapu $1.5 \mathrm{~kg}$ dengan penurunan sebesar $55,76 \%$ yang dilihat dari hari ke-3 sampai hari ke-9. Kenaikan efisiensi penurunan BOD pada masing-masing bak dari hasil ke-3 sampai ke-9 disebabkan oleh konsentrasi BOD yang diasosiasikan dengan padatan tersuspendi yang dapat mengendap lebih banyak daripada yang dapat terlarut. Karena ini $80 \%$ dari BOD terdiri dari padatan terlarut (tersuspensi), padatan tersuspensi dapat dibagi menjadi padatan yang tersuspensi dan padatan yang tidak tersuspensi. Pada umumnya $60 \%$ dari padatan tersuspensi di dalam air limbah adalah padatan yang mengendap. Penyisihan fisik dari BOD terjadi dari proses pengendapan dan penangkapan material partikulat. BOD terlarut disisihkan oleh oleh pertumbuhan pada permukaan air limbah yang menempel pada akar dan penetrasi rhizoma. (Pinton,2001). Mikroorganisme memegang peranan penting dalam penghilangan bahan organic yang proses penguraiannya membutuhkan oksigen. Oksigen tersebut mengalir ke akar melalui batang yang berdifusi dengan atmosfer melalui pori-pori daun. (Vymazal,2008). Sehingga pada air limbah yang ditanam dengan tanaman apu-apu akan mengalami penurunan kadar BODnya.

Hasil penelitian ini Berdasarkan uji Mannwhitney dapat disimpulkan bahwa berat yang efektif dalam menurunkan kadar BOD air limbah Rumah Sakit terdapat air limbah tahu terdapat pada berat $1.5 \mathrm{~kg}$ dengan kadar BOD sebesar 12.65 , hal ini dikarenakan pada berat ini sudah mampu menurunkan hingga dibawah baku mutu Menurut Peraturan Gubernur Lampung No. 7 tahun 20010 tentang Baku Mutu Air Limbah Rumah Sakit, yang menyatakan bahwa batas baku mutu BOD adalah $30 \mathrm{mg} / \mathrm{L}$. Sedangkan pada kelompok yang lain tidak ada perbedaan kadar BOD.

Untuk mengetahui keefektifan lama waktu kontak dalam menurunkan kadar BOD dapat dilihat pada Tabel 4.6 Dengan uji Mannwhitney kelompok yang mempunyai perbedaan kadar $\operatorname{BOD}(P)<0,05$ adalah dari hari ke-0 dan hari ke-3 dan hari k-6 dan hari ke-9, dari hari ke-3 dan 6 hari dan 9 hari, serta dari hari ke-6 dan hari ke-9. Hasil penelitian ini Berdasarkan uji Mann- whitney dapat disimpulkan bahwa lama waktu yang efektif dalam menurunkan kadar BOD air limbah Rumah Sakit terdapat air limbah tahu terdapat pada hari ke 9 dengan kadar BOD sebesar 12.65, hal ini dikarenakan pada lama waktu kontak ini sudah mampu menurunkan hingga dibawah baku mutu Menurut Peraturan Gubernur Lampung No.7 tahun 20010 tentang Baku Mutu Air Limbah Rumah Sakit, yang menyatakan bahwa batas baku mutu BOD adalah $30 \mathrm{mg} / \mathrm{L}$. Semakin lama waktu kontak tanaman dengan air limbah semakin baik dalam penurunan kadar BOD,

\section{Penurunan COD}

Berdasarkan hasil penelitian yang telah dilakukan tabel 2, pada pengamatan hari ke-0 menuju hari ke-3 sampai hari ke-9 dengan berat masing-masing $0,5 \mathrm{~kg}, 1 \mathrm{~kg}$, dan $1,5 \mathrm{~kg}$, mengalami penurunan COD pada masingmasing bak yang digunakan untuk perlakuan. Penurunan yang paiing tinggi adalah pada hari ke-9 dengan berat $1,5 \mathrm{~kg}$ sebesar $61,82 \%$. Hal ini disebakan oleh akar tanaman apu-apu telah tumbuh dan dapat menyebar dengan baik karena telah melakukan aklimitasi yang cukup sehingga penurunan COD pada semua bak mengalami kenaikan yang cukup besar. Bahan organic didegradasi oleh mikroorganisme yang tumbuh pada permukaan air limbah dan menempel pada akar tanaman, serta penetrasi rhizoma pada air limbah( Pinton,2001). Akar tanaman yang semakin banyak karena pertumbuhannya semakin lama akan meningkatkan suplai oksigen. Sehingga memperluas zone rizhosfer dan mampu memperluas lekat mikroorganisme yang berperan dalam penguraian padatan (Gregory,2006). Oleh sebab itu, semakin lamanya waktu yang digunkan semakin baik juga tanaman apu-apu meningkatkan suplai oksigen yang dibutuhkan oleh air limbah tersebut dan memperkecil kadar COD dalam air limbah.

Hasil penelitian ini Berdasarkan uji Mannwhitney dapat disimpulkan bahwa berat yang efektif dalam menurunkan kadar COD air limbah Rumah Sakit terdapat air limbah tahu terdapat pada berat $1,5 \mathrm{~kg}$ dengan kadar COD sebesar 32.00, hal ini dikarenakan pada berat ini sudah mampu menurunkan hingga dibawah baku mutu Menurut Peraturan Gubernur 
Lampung No.7 tahun 20010 tentang Baku Mutu Air Limbah Rumah Sakit, yang menyatakan bahwa batas baku mutu COD adalah $80 \mathrm{mg} / \mathrm{L}$. Sedangkan pada kelompok yang lain tidak ada perbedaan kadar COD. Untuk mengetahui lama waktu kontak dalam menurunkan kadar COD dapat dilihat pada Tabel 4.8 Dengan uji Mannwhitney kelompok yang mempunyai perbedaan kadar $\operatorname{COD}(P)<0,05$ adalah dari hari ke-0 dan hari ke-3 dan hari k-6 dan hari ke-9, dari hari ke-3 dan 6 hari dan 9 hari, serta dari hari ke-6 dan hari ke-9., lalu dari hari ke-3 dan hari ke-9.

Hasil penelitian ini Berdasarkan uji Mannwhitney dapat disimpulkan bahwa lama waktu yang efektif dalam menurunkan kadar COD air limbah Rumah Sakit terdapat air limbah tahu terdapat pada hari ke 9 dengan kadar COD sebesar 32.00, hal ini dikarenakan pada lama waktu kontak ini sudah mampu menurunkan hingga dibawah baku mutu Menurut Peraturan Gubernur Lampung No.7 tahun 20010 tentang Baku Mutu Air Limbah Rumah Sakit, yang menyatakan bahwa batas baku mutu COD adalah $80 \mathrm{mg} / \mathrm{L}$. Semakin lama waktu kontak tanaman dengan air limbah semakin baik daiam penurunan kadar COD.

\section{Penurunan Amoniak}

Berdasarkan hasil penelitian, yang telah dilakukan (tabel 3) pada pengamatan hari ke-0 menuju hari ke-3 sampai hari ke-9 mengalami penurunan amoniak pada masing-masing bak yang digunakan untuk perlakuan. Peraturan Gubernur Lampung No.7 tahun 2007 tentang Baku Mutu Air Limbah Rumah Sakit, ini adalah peraturan yang dipakai dalam Rumah Sakit TK IV 02.07.04 / DKT. Dengan batas baku mutu yang diperblehkan $0,1 \mathrm{mg} / \mathrm{L}$. Penurunan yang paling tinggi adalah pada hari ke- 9 dengan berat $1,5 \mathrm{~kg}$ sebesar $97.12 \%$. Dalam hal ini dapat dilihat jumlah tanaman apu-apu yang digunakan, semakin banyak tanaman semakin baik dalam penurunan kadar amonia. Selain itu, tanaman apu-apu dapat tumbuh subur dengan adanya amonia, karena amonia merupakan asupan makanan untuk tanaman apu-apu. Selain itu tanaman ini memiliki masa optimal dalam menurunkan kadar amonia dalam air. (Liani, 2004), karena pada hari ke-9 tanaman ini mencapai puncaknya untuk melakukan penyerapan. Tanaman ini juga memiliki masa jenuh dalam menyerap. Sehingga pada hari ke-10-15 tanaman ini ada mulai melipat gandakan populasinya, dan bila semakin banyak tanaman apu-apu yang tumbuh maka semakin sulit juga tanaman menyerap kandungan yang berada dalam air $1 \mathrm{mbah}$.

Hasil penelitian ini Berdasarkan uji Mannwhitney dapat disimpulkan bahwa berat yang efektif dalam menurunkan kadar amoniak air limbah Rumah Sakit terdapat pada berat $1.5 \mathrm{~kg}$ dengan kadar amoniak sebesar 0.015 , hal ini dikarenakan pada berat ini sudah mampu menurunkan hingga mendekati bakụ mutu Menurut Peraturan Gubernur Lampung No.7 tahun 20010 tentang Baku Mutu Air Limbah Rumah Sakit, yang menyatakan bahwa batas baku mutu amoniak adalah $0,1 \mathrm{mg} / \mathrm{L}$. Sedangkan pada kelompok yang lain tidak ada perbedaan kadar amoniak.

Hasil penelitian ini Berdasarkan uji Mannwhitney dapat disimpulkan bahwa lama waktu yang efektif dalam menurunkan kadar amoniak air limbah Rumah Sakit terdapat air limbah tahu terdapat pada hari ke 9 dengan kadar amoniak sebesar 0.15 , hal ini dikarenakan pada lama waktu kontak ini sudah mampu menurunkan hingga mendekati batas baku mutu Menurut Peraturan Gubernur Lampung No.7 tahun 20010 tentang Baku Mutu Air Limbah Rumah Sakit, yang menyatakan bahwa batas baku mutu amoniak adalah $0,1 \mathrm{mg} / \mathrm{L}$. Semakin lama waktu kontak tanaman dengan air limbah semakin baik dalam penurunan kadar amoniak.

\section{Penurunan $\mathrm{pH}$}

Nilai $\mathrm{pH}$ hasil pengukuran pada limbah cair rumah sakit menunjukan bahwa netral. Dari hasil yang dapat dilihat dari tabel 4.4 menunjukkan bahwa $\mathrm{pH}$ mengalami penurunan, walaupun penurunan tersebut hanya berkisar dari 0,1 sampai 0,3 dalam lama waktu 3 ahri, 6 hari dan 9 hari dengan tanaman apu-apu $0,5 \mathrm{~kg}$, $1 \mathrm{~kg}$, dan $1,5 \mathrm{~kg}$. Perubahan nilai $\mathrm{pH}$ selam proses fitoremediasi terjadi karena terjadi akibat aktivitas biokimia mikroorganisme yang terdapat dalam air limbah dan akar tanaman apu-apu. Mikroorganisme tersebut akan mendegradasi deterjen menjadi senyawa yang sederhana yaitu asam amino dan asam lemak (asam organik). Dengan terbentuknya asam organik hasil pemecahan protein dan lemak, maka derajat keasaman akan terus menurun mendekati $\mathrm{pH}$ netral. Nilai $\mathrm{pH}$ erat kaitannya dengan nilai karbondioksida, semakin tinggi nilai karbondioksida di dalam air limbah maka nilai $\mathrm{pH}$ juga akan semakin rendah.

Tanaman apu-apu mampu bertahan hidup dari $\mathrm{pH} 4,5$ sampai dengan 10. Tetapi suhu optimal untuk pertumbuhan tanaman apu-apu 
adalah ph 6 sampai dengan 8 . Pada pH yang rendah pertumbuhan tumbuhan tanaman akan terhambat, hal tersebut terjadi akibat rendahnya ketersediaan unsur hara yang dibutuhkan oleh tumbuhan. Bila $\mathrm{pH}$ air lebih rendah dari 4,0 pada umumnya akan terjadi kenaikan $\mathrm{Al}^{3+}$. Hal tersebut akan berdampak secara fisik yaitu merusak sistem perakaran, terutama akar-akar muda, sehingga pertumbuhan tanaman menjadi terhambat. Konsentrasi Alumunium yang tinggi memungkinkan terjadinya ikatan terhadap fosfor dalam bentuk alumunium fosfat. P yang terikat oleh alumunium tidak dapat digunakan oleh tanaman, sehingga penyerapan fosfat terhambat.

Tanaman yang ditanam pada $\mathrm{pH}$ rendah biasanya juga menunjukkan klorosis atau peleburan klorofil sehingga daun tumbuhan berwarna pucat. Kondisi $\mathrm{pH}$ cukup mempengaruhi kemampuan tumbuhan menyerap zat pencemar. Sehingga dari hari 3,6, dan 9 pertumbuhan tanaman terjadi terus menurus. Dengan penurunan kadar $\mathrm{pH}$ yang tidak banyak, dan masih masuk ke dalam hatas netral.

\section{KESIMPULAN}

1. Perbedaan dan efektivitas berat apu-apu terhadap penurunan BOD yaitu pada berat $1,5 \mathrm{~kg}$ dan lama waktu kontak efektif adalah pada hari ke-9.

2. Perbedaan dan efektivitas berat apu-apu terhadap penurunan COD yaitu pada berat yang paling efektif adalah berat 1,5 kgdan lama waktu kontak efektif adalah pada hari ke-9.

3. Perbedaan dan efektivitas berat apu-apu terhadap penurunan amoniak yaitu pada berat 1,5 kgdan lama waktu kontak yang efektif adalah pada hari ke-9.

\section{DAFTAR PUSTAKA}

Asmadi, 2013. Pengelolaan Limbah Medis Rumah Sakit. Yogyakarta : Gosyen Publishing. 136 halaman

Abadi, A.L., 2010. Ilmu Tumbuhan. Bayu Media Publishing: Malang

Dharmono,2007. Perpustakaan Sekolah. PT.Tira Pustaka : Jakarta
Forestier,H. 2007. Prasejarah Kepulauan Indonesia. Gramedia Pustaka Utama : Jakarta

Kumar, R. 2008. Review Of Plants. John Press : Toronto

Landprotection,2006. In Asive Plants. Century Crafts : New York

Langeland, G. 2008. Code For Practice For Powdered Formula For Plants. PT.Gramedia Pustaka Utama : JakartA

Matthews,I.G. 2003. The Island. 2nd. Island Press : Washington

Robert,R. 2008. Buku Pintar. Media Of Indonesia : Jakarta

Hastono; Sabri, : Luknis,2010, Statistik kesehatan. Jakarta: PT. Raja Grafindo. 208 halaman

Riwidikko,Handoko,2010, Statistik Kesehatan;Dagaran Bangunharjo; Yogyakarta; 162

1204/MenKes/SK/IX/2004 Tentang Persyaratan Kesehatan Lingkungan Rumah Sakit. Jakarta

Suci, Handayani, 2005, Fitoremediasi Dengan Eceng Gondok, Jakarta.

Sujaweni V. Wiratna. 2015. Statistika Untuk Kesehatan. Yogyakarta. Gava Media

Utomo., 2011.Instalasi Pengolahan Air Limbah di Rumah Sakit DKT. Bandar Lampung

Siregar, Sakti.A., 2005. Instalasi Pengolahan Air Limbah. Yogyakarta : Kanisius.111 halaman

Sugiharto.1987.Dasar-Dasar Pengolahan Air Limbah. Jakarta : Universitas Indonesia. 190 halaman.

Peraturan Gubernur Lampung Tahun 2010 Tentang Baku Mutu Air Limbah Rumah Sakit.

Vymazal,J., 2008. Waterwate Treatment in Constructed Wetlands with Horizontal subSurface Flow. ICzech Republic: Springer.

UU No.32 tahun 2009 Tentang Perlindingan dan Pengelolaan Lingkungan Hidup.

Puspita, dkk., 2011. Kemampuan Tumbuhan Air sebagai Agen Fitoremediasi Logam Berat Kromium yang terdapat pada limbah cair Industri batik. Jurnal berkala perikanan Terubuk. 